\title{
Rodez « Segodunum »
}

Les Attizals

\section{(2) OpenEdition \\ Journals}

Édition électronique

URL : http://journals.openedition.org/adlfi/10549

ISSN : 2114-0502

Éditeur

Ministère de la culture

\section{Référence électronique}

"Rodez «Segodunum » , ADLFI. Archéologie de la France - Informations [En ligne], Midi-Pyrénées, mis en ligne le 01 mars 1997, consulté le 02 mai 2019. URL : http://journals.openedition.org/adlfi/10549

Ce document a été généré automatiquement le 2 mai 2019.

(C) Ministère de la Culture et de la Communication, CNRS 


\title{
Rodez « Segodunum »
}

\author{
Les Attizals
}

Date de l'opération : 1990 (DF)
Inventeur(s) : Dausse Lucien

1 Le redressement d'un talus,consécutif à l'élargissement du CD 84, au pied sud-est de la butte de Rodez, en bordure de l'Aveyron, a permis de mettre au jour les vestiges d'un habitat antique [ (Fig. $\mathrm{n}^{\circ} 1$ : Plan général), plan général, site f]. Sous $3 \mathrm{~m}$ de terre végétale sont apparus deux niveaux de sol aménagés dans le gneiss et séparés par un mur de refend conservé sur $0,60 \mathrm{~m}$ de hauteur.

2 Le mobilier archéologique récupéré dans les déblais permet tout au plus d'avancer une chronologie d'ensemble comprise dans le $\mathrm{I}^{\mathrm{er}}$ s. avant J.-C. (amphores Dr. 1, céramique italique à vernis noir, campanienne B ou B-oïde) et les $\mathrm{I}^{\mathrm{er}} \mathrm{s}$. et $\mathrm{II}^{\mathrm{e}} \mathrm{s}$. après J.-C. (amphores Dr. 20, céramiques sigillées sud-gauloises, cruches blanches peintes, céramiques communes).

\section{ANNEXES}


Fig. $n^{\circ} 1$ : Plan général

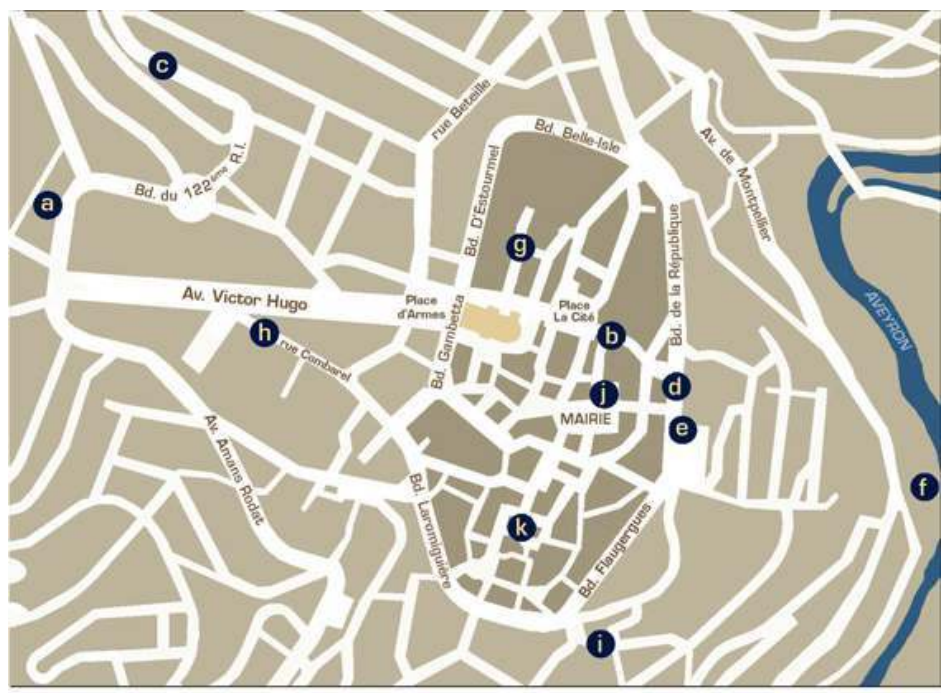

Plan général : RoDez

Localisation des fouilles effectuées dans la ville

a) Caserne Rauch

b) rue Aristide-Briand

c) boulevard du $122^{\mathrm{e}}$ régiment

d'Infanterie

d) 22 , boulevard Denys-Puech

e) place Clémenceau

f) Les Attizals

g) 3, impasse Cambon h) 25 , rue Combarel

i) La Tour de la Boule d'Or, boulevard

Flaugergues

j) Les Jacobins, Raynaldi-J aurès

k) autour de l'église Saint-Aman

(rue Villaret, place des Toiles,

rue Cassagnes, rue de la Madeleine,

rue Lebon)

GI 1997 ; CNRS Éditions 1998 (1997)

INDEX

Index chronologique : Âge du Fer, Haut-Empire

Index géographique : Midi-Pyrénées, Aveyron, Rodez

operation découverte fortuite (DF) 